\title{
Electrocoagulation of Landfill Leachate with Monopolar Aluminum Electrodes
}

\author{
Tezcan Un U. and Oduncu E.
}

\begin{abstract}
In this paper, the removal of COD from landfill leachate using aluminum electrode by the electrocoagulation method was investigated. The studies were run with the parallel plate monopolar aluminum electrodes and the effect of $\mathrm{pH}$ and current density on removal efficiency of COD and energy consumption were determined. The initial COD concentration of $4100 \mathrm{mg} / \mathrm{L}$ was reduced to $1763 \mathrm{mg} / \mathrm{L}$ with the removal efficiency of $57 \%$ at the current density of $75 \mathrm{~mA} / \mathrm{cm}^{2}$ and $\mathrm{pH} 5$.
\end{abstract}

Index Terms-Aluminium electrode, landfill leachate, treatment.

\section{INTRODUCTION}

The most common and desirable integral indispensable solid waste management strategy is sanitary landfilling because it is simple and has low exploitation and capital costs. Up to $95 \%$ of the total municipal solid waste collected in the world is disposed of in landfills [1]. Physico-chemical and biological conversions are occurred during the landfilling process and a result of conversions degregated organic compounds that soluble in rainwater are formed. Any liquid material that drains from land material is called "leachate" and it is highly toxic liquid with dissolving organic compounds, heavy metals and different soluble materials derived from the material that it has passed through. The composition of leachate from a landfill depends on the age of the landfill and the type of waste that it contains. Leachate can potentially contaminate nearby surface and ground water if left untreated. Therefore landfills require close environmental monitoring during their design, operation, and long-term post-closure period.

Leachate must be treated before discharging to environment. Many different physico-chemical techniques such as adsorption [2], chemical precipitation [3], coagulation/flocculation [4], chemical oxidation [5] and biological methods [6] have been being applied for the treatment of landfill leachate. Electrocoagulation, one of the most useful electrochemical methods, is a comparatively new technique for wastewater treatment. Also, electrocoagulation has some advantages such as, short retention time, easy operation, not needed the chemical addition, simple equipment, high sedimentation velocity and possibility of complete automation [7].

Manuscript received April 11, 2013; revised June 28, 2013.

U. Tezcan Un. and E. Oduncu. are with the Department of Environmental Engineering, Anadolu University Eskisehir, Turkey (e-mail: utezcan@anadolu.edu.tr).

\section{Electrocoagulation}

Electrocoagulation is based on the electric charge stability of colloids, emulsions and suspension. It is known that, particles are charged neutral in the wastewater. However, the surface charge of the particles tends to be neutralized, opposite charged particles combine and make larger floccules, when the additional electric charges are provided to the particles with appropriate electrodes [8].

In electrocoagulation process aluminum or iron electrodes as sacrificial anodes are dissolved to produce their cations upon the application of a direct current. The metal ions generated are hydrolyzed in the electrochemical cell to produce metal hydroxide ions according to reactions (1)-(3) [9].

$$
\begin{gathered}
\mathrm{Al} \rightarrow \mathrm{Al}^{3+}{ }_{(\mathrm{aq})}+3 \mathrm{e}^{-} \\
\mathrm{Al}^{3+}{ }_{(\mathrm{aq})}+3 \mathrm{H}_{2} \mathrm{O} \rightarrow \mathrm{Al}(\mathrm{OH})_{3}+3 \mathrm{H}^{+}{ }_{(\mathrm{aq})} \\
n \mathrm{Al}(\mathrm{OH})_{3} \rightarrow \mathrm{Al}_{n}(\mathrm{OH})_{3 n}
\end{gathered}
$$

Metal complexes further react with negatively charged particles in the solution to form flocs. The $\mathrm{pH}$ and ionic strength of solution determines the type and solubility of metal hydroxide complexes formed.

Insoluble flocs of $\mathrm{Al}(\mathrm{OH})_{3}$ are generated at $\mathrm{pH}$ range between 6.0 and 7.0. However, depending on the $\mathrm{pH}$ of the aqueous medium other ionic species, such as $\mathrm{Al}(\mathrm{OH})^{2+}, \mathrm{Al}_{2}(\mathrm{OH})_{2}{ }^{4+}$ and $\mathrm{Al}(\mathrm{OH})_{4}$ may also be present in the system [10], [11].

The aim of this study was to treat the landfill leachate by electrocoagulation (EC). In this purpose the parallel plate aluminum electrodes were used. This study elucidates the effects of parameters such as: initial $\mathrm{pH}$ and current density on the COD removal efficiency for a batch EC reactor. Information regarding the electrical energy consumption (EEC) is also included to provide an estimation of the cost of COD removal by an EC system.

\section{MATERIALS AND METHODS}

\section{A. Leachate}

The leachate was collected from landfill in Izmit/Turkey. In this landfill area 3.106.028 tons of domestic and household waste, 297.485 tons of domestic industrial waste were received between 1997-2011. The leachate wastewater taken from this area was stored at refrigerator and used without any pre-treatment. It has strong odor and dark brown/black color with a $\mathrm{pH}$ of 9 and COD concentration of $4100 \mathrm{mg} / \mathrm{L}$. 


\section{B. Bench Scale Batch EC Apparatus}

Experimental set-up was consisted of DC power supply (Statron 2257), magnetic stirrer (IsoLab MS-010) and EC reactor. In the electrochemical cell, six aluminum plates (dimension $4 \mathrm{~cm} \times 4.5 \mathrm{~cm}$ ) with the anode surface area of 108 $\mathrm{mA} / \mathrm{cm} 2$ were used as electrodes. The electrodes were connected using a monopolar configuration which three aluminum plate operated as anode in the electrocoagulation reactor. The detail of reactor is shown in Fig. 1. The reactor was dipped in wastewater in glass beaker. Also, beaker was dipped into water-bath to stabilize temperature increase.

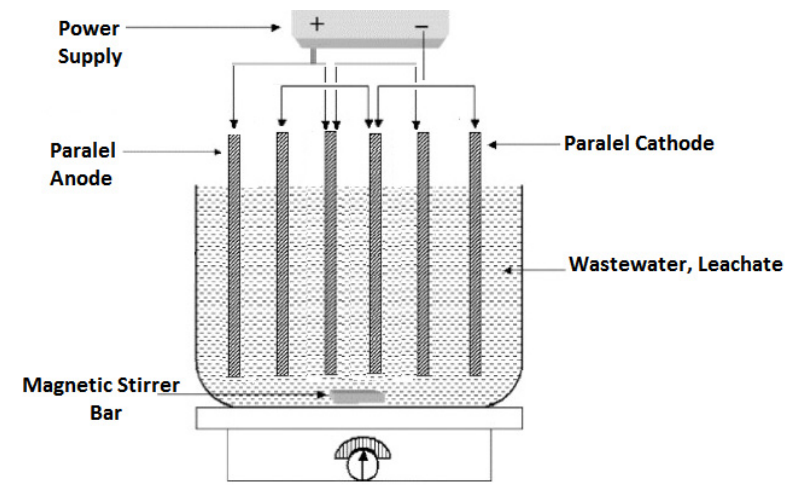

Fig. 1. Experimental setup.

\section{Experimental Procedure}

In this study, $0.4 \mathrm{~L}$ wastewater was poured into the electrochemical cell and electrocoagulation experiments were performed for $60 \mathrm{~min}$ for each run. Samples were taken every $15 \mathrm{~min}$ interval from the electrocoagulator, filtered and analyzed to determine COD concentrations using Close-Reflux Methods.

All the samples were analyzed in duplicate to ensure data reproducibility, and an additional measurement was carried out, if necessary. The calculation of removal efficiency $(R E \%)$ after EC was calculated using the equation

$$
R E \%=\left(\left(C_{o}-C\right) / C_{o}\right) \times 100
$$

where $C_{o}$ and $C$ are the concentrations of COD before and after $\mathrm{EC}$, respectively, in $\mathrm{mg} / \mathrm{L}$.

Additionally, energy consumption $\left(\mathrm{E}_{\mathrm{c}} ; \mathrm{kWh} / \mathrm{m}^{3}\right)$ was calculated using following equation;

$$
E_{c}=V \times I \times T / v_{w}
$$

where $\mathrm{V}$ is Voltage (V), I is Current (A), $\mathrm{T}$ is operation time $(\mathrm{h})$, and $\mathrm{v}_{\mathrm{w}}$ is the volume of the wastewater $\left(\mathrm{m}^{3}\right)$.

\section{RESUlTS AND DISCUSSION}

\section{A. Effect of Initial $p H$}

$\mathrm{PH}$ has an important role in the EC process. The effect of initial $\mathrm{pH}$ was studied in the ranges of 3-9 at the current density of $30 \mathrm{~mA} / \mathrm{cm}^{2}$. The initial $\mathrm{pH}$ of the wastewater was adjusted using $1 \mathrm{~N}_{2} \mathrm{SO}_{4}$. In all experiments, $\mathrm{pH}$ was not controlled but monitored during operation. Although $\mathrm{pH}$ increases during EC process due to hydroxyl ions release.

The effect of $\mathrm{pH}$ on removal efficiency is presented in Fig.
2. After 60 minutes EC removal efficiencies were $46 \%, 48 \%$, $42 \%$, and $40 \%$ at the $\mathrm{pH}$ of $3,5,7$, and 9 , respectively. The best removal efficiency was obtained at $\mathrm{pH} 5$ because the hydrolysis of $\mathrm{Al}^{3+}$ depends on $\mathrm{pH}$. At higher $\mathrm{pH}$, the dominant compound is $\mathrm{Al}(\mathrm{OH})_{4}{ }^{-}$, which is not able to coagulate with pollutants [12], [13].

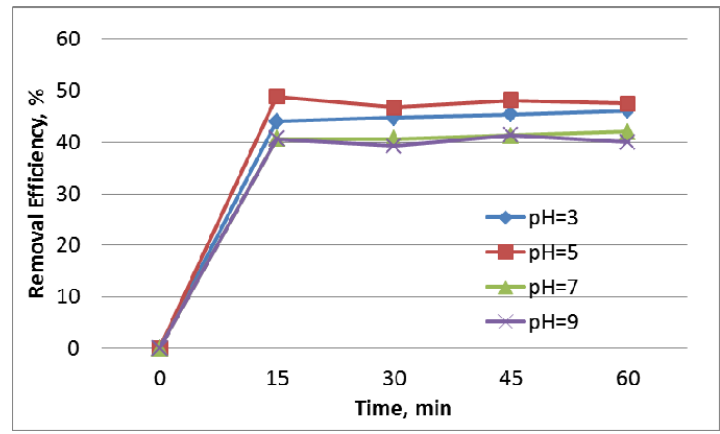

Fig. 2. Variation of effluent COD with time at the different $\mathrm{pH}$.

The effect of $\mathrm{pH}$ on energy consumption is shown in Fig. 3 Energy consumption is expressed with $\mathrm{kWh}$ per $\mathrm{m}^{3}$. Electrical conduction is a phenomenon in which is able to carry electricity. The decreasing $\mathrm{pH}$ of solution causes to increase in conductivity. So, when the conductivity increases, ability to carry electricity is also increased and low energy needed. That can explain the relation between $\mathrm{pH}$ and energy consumption [14]. The energy consumptions were 42, 52, 49 and $125 \mathrm{kWh} / \mathrm{m}^{3}$ at $\mathrm{pH}$ of $3,5,7$, and 9 , respectively after 60 minutes EC operation.

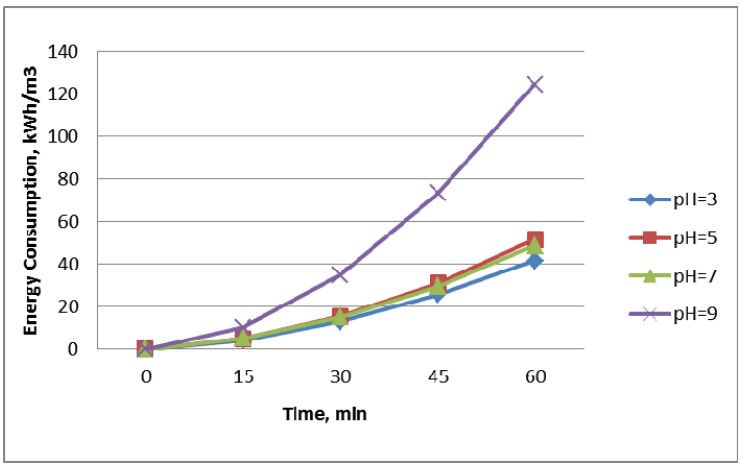

Fig. 3. Variation of electrical energy consumption with initial $\mathrm{pH}$.

\section{B. Effect of Current Density}

Current density is defined as current applied per unit surface area of the electrode. Current density is the operational parameter which is the easiest to control and determines coagulant dosage and bubble generation rates. According to Faraday's law (Eq. 6), the amount of ions released from anode increases with increasing current (I).

$$
m=I \times t \times M /(z \times F)
$$

where $m$ is the mass of generated metal ions (gram); $I$ is the current(Ampere), $t$ is the operation time (min,h); $M$ is the atomic weight of metal $(\mathrm{g} / \mathrm{mol}), z$ is the number of electrons transferred in the anodic dissolution ( $z=3$ for Aluminum), and $F$ is Faraday's constant $\left(96486 \mathrm{C} \mathrm{eq}^{-1}\right)$.

The effect of current density was determined at the $\mathrm{pH}$ of 5 and results can be seen from Fig. 4. As seen from Fig. 4 the removal efficiencies were not change significantly after 15 min. of EC. The removal efficiencies of $49 \%, 47 \%, 50 \%$, $51 \%, 50 \%$ were obtained after 15 minutes EC at the current 
densities of $30,45,55,65,75 \mathrm{~mA} / \mathrm{cm}^{2}$, respectively. Further electrocoagulation to $45 \mathrm{~min}$ the removal efficiencies of $48 \%$, $47 \%, 48 \%, 52 \%$ and $57 \%$ were obtained at the current densities of $30,45,55,65,75 \mathrm{~mA} / \mathrm{cm}^{2}$, respectively.

The energy consumption depends on time as well as the current and potential that are applied (Eq. 5). As the reaction time increased, the system energy consumption also increased. As it can be seen from Fig. 5 increasing current resulted with increasing energy consumption. After 15 minutes EC the electrical energy consumptions of 5, 10, 13, $16,26 \mathrm{kWh} / \mathrm{m}^{3}$ were obtained current densities of $30,45,55$, $65,75 \mathrm{~mA} / \mathrm{cm}^{2}$, respectively. As the time proceeds the final COD concentration did not change significantly beyond 15 minutes. Therefore the long reaction time was not preferred from an economical viewpoint.

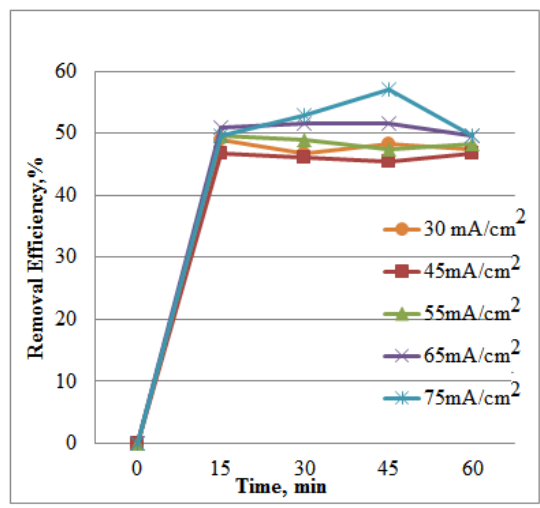

Fig. 4. Variation of removal efficiency with time at different current densities.

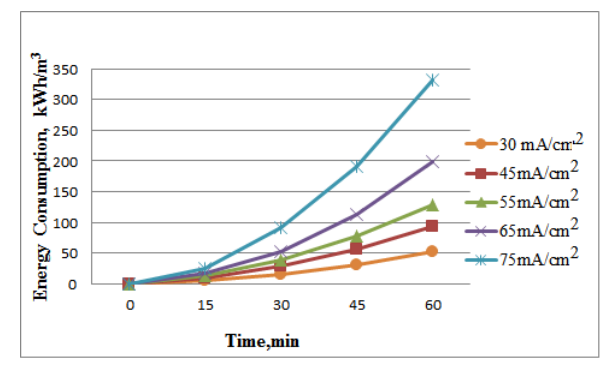

Fig. 5. Variation of electrical energy consumptions with current densities.

\section{CONCLUSION}

Based on the results achieved from the experiments, the following conclusions may be outlined:

1) Electrocoagulation with aluminum electrode could be applicable for the treatment of landfill leachate.

2) The treatment of landfill leachate by electrocoagulation was found to be $\mathrm{pH}$ dependent. The highest removal efficiency was achieved at $\mathrm{pH} 5$.

3) The removal efficiencies increased by increasing the current density while increasing the current density caused the energy consumption to increase. The energy consumption also depends on time. The removal efficiency of $51 \%$ was obtained with the energy consumption of $16 \mathrm{kWh} / \mathrm{m}^{3}$ after 15 min electrocoagulation.

\section{ACKNOWLEDGEMENTS}

This study was supported by Anadolu University Scientifi c Research Projects Commission under the grant no: 1304F 065, Turkey.

\section{REFERENCES}

[1] K. Y. Foo and B. H. Hameed, "An overview of landfill leachate treatment via activated carbon adsorption process," Review Article J. Hazard. Mater, vol. 171, Issues 1-3, pp. 54-60, November 2009.

[2] K. Y. Foo, L. K. Lee and B. H. Hameed, "Batch adsorption of semi-aerobic landfill leachate by granular activated carbon prepared by microwave heating," Chemical Engineering Journal, vol. 222, pp. 259-264, April 2013.

[3] T. Zhang, L. Ding and H. Ren, "Pretreatment of ammonium removal from landfill leachate by chemical precipitation," J. Hazard Mater, vol. 166, Issues 2-3, pp. 911-915, July 2009.

[4] J. S. Guo, A. A. Abbas, Y. P. Chen, Z. P. Liu, F. Fang and P. Chen, "Treatment of landfill leachate using a combined stripping, Fenton, SBR, and coagulation process," J. Hazard. Mater, vol. 178, Issues 1-3, pp. 699-705, June 2010.

[5] S. K. Singh and W. Z. Tang, "Statistical analysis of optimum Fenton oxidation conditions for landfill leachate treatment," Waste Management, vol. 33, Issue 1, pp. 81-88, January 2013.

[6] Z. Y. Xu, G. M. Zeng, Z. H. Yang, Y. Xiao, M. Cao, H. S. Sun, L. L. Ji and Y. Chen, "Biological treatment of landfill leachate with the integration of partial nitrification, anaerobic ammonium oxidation and heterotrophic denitrification," Bioresource Technology, vol. 101, Issue 1, pp. 79-86, January 2010.

[7] U. Tezcan Un, A. S. Koparal, U. Bakır Ogutveren, "Electrocoagulation of vegetable oil refinery wastewater using aluminum electrodes," $J$. Environ. Manag., vol. 90, pp. 428-433, 2009.

[8] A. S. Koparal, U. Bakir and Ogutveren, "Removal of nitrate from water by electroreduction and electrocoagulation," J. Hazard. Mater., vol. 89, issue 1, pp. 83-94, January, 2002.

[9] U. Tezcan Un, A. S. Koparal, and U. Bakır Ogutveren, "Electrocoagulation of vegetable oil refinery wastewater using aluminum electrodes," Journal of Environmental Management, vol. 90, Issue 1, pp. 428-433, January 2009.

[10] M. Y. Mollah, R. Schennach, J. R Parga and D. L Cocke, "Electrocoagulation, science and applications," J. Hazard. Mater., vol. 89, issue 1, pp. 29-41, June 2001.

[11] F. Bouhezila, M. Hariti, H. Lounici and N. Mameri, "Treatment of the OUED SMAR town landfill leachate by an electrochemical reactor," Desalination, vol. 280, issue 1-3, pp. 347-353, October, 2011.

[12] P. K. Holt, G. W. Barton, M. Wark and C. A. Mitchell, "A quantitative comparison between chemical dosing and electrocoagulation," Colloids Surf. A, vol. 221, issue 2-3, pp. 223-248, December, 2002.

[13] C. Wang, W. L. Chou and Y. M. Kuo, "Removal of COD from laundry wastewater by electrocoagulation/ electroflotation," J. Hazard. Mater., vol. 164, pp. 81-86, May 2009.

[14] A. E. Yilmaz, R. Boncukcuoglu, and M. M. Kocakerim "An empirical model for parameters affecting energy consumption in boron removal from boron-containing wastewaters by electrocoagulation," J. Hazard. Mater., vol. 144, pp. 101-107, June 2007.

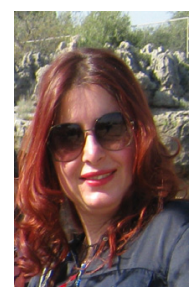

Umran Tezcan Un was born in 1971 in Eskisehir, Turkey. She graduated from Department of Chemical Engineering, Anadolu University in 1992 and achieved to study Environmental Engineering at Anadolu University.

She is currently an associate professor at Anadolu University, Department of Environmental Engineering. She has 21 years of teaching and research experience in the field of environmental science and technology. Her research spans are industrial pollution control, water treatment and electrochemical treatment methods. She has directed and supervised numerous research studies and projects in the field of wastewater management and industrial pollution control.

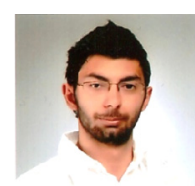

Emre Oduncu was born in December 3, 1989 in Istanbul Turkey. He graduated from Department of Biology and Department of Chemistry at the same time, Eskisehir Osmangazi University/Turkey in 2011. Now he has two bachelor degree (Chemistry and Biology).

$\mathrm{He}$ is a master student in Department of Environmental Engineering at Anadolu University, Turkey. His research spans are electrochemical treatment methods, leachate treatment. 